\title{
COVID19 vaccine type and humoral immune response in patients receiving dialysis
}

Authors

Pablo Garcia, MD, Department of Medicine (Nephrology), Stanford University^

Shuchi Anand, MD, Department of Medicine (Nephrology), Stanford University^

Jialin Han, MS, Department of Medicine (Nephrology), Stanford University

Maria Montez-Rath, PhD, Department of Medicine (Nephrology), Stanford University

Sumi Sun, MPH, Satellite Healthcare

Tiffany Shang, PharmD, Satellite Healthcare

Julie Parsonnet, MD, Departments of Medicine (Infectious Diseases and Geographic Medicine), and Epidemiology and Population Health, Stanford University

Glenn M Chertow, MD, Departments of Medicine (Nephrology), and Epidemiology and

Population Health, Stanford University

Brigitte Schiller, MD, Satellite Healthcare^

Graham Abra, MD, Satellite Healthcare ${ }^{\wedge}$

$\wedge^{\wedge}$ contributed equally

Word count: 743 (Max 800)

Correspondence to:

Pablo Garcia, MD

777 Welch Road Suite DE

Palo Alto California, US 94304

pgarciah@stanford.edu

ph: 7329255825

Keywords: dialysis, covid-19, vaccine, SARS-CoV-2, ESRD 


\section{ABSTRACT}

\section{Background}

Patients on dialysis vaccinated with the attenuated adenovirus SARS-CoV-2 vaccine might mount an impaired response to vaccination.

\section{Methods}

We evaluated the humoral vaccination response among 2,099 fully vaccinated patients receiving dialysis. We used commercially available assays (Siemens) to assess prevalence of no response or diminished response to COVID-19 vaccination by vaccine type. We defined "no seroconversion" as lack of change from negative to positive in total RBD Ig antibody, no detectable response on semiquantitative RBD IgG antibody (index value <1) as "no RBD IgG response", and a semiquantitative RBD IgG index value $<10$ as "diminished RBD IgG response"

\section{Results}

Of the 2,099 fully vaccinated patients on dialysis, the proportion receiving the mRNA1273, BNT162b2, and Ad26.COV2.S were 62\% $(n=1316), 20 \%(n=416)$ and $18 \%(n=367)$, respectively. A third (33.3\%) of patients receiving the attenuated adenovirus Ad26.COV2.S vaccine failed to seroconvert and an additional $36 \%$ had no detectable or diminished IgG response even 28-60 days post vaccination.

\section{Conclusion}

One in three fully vaccinated patients receiving dialysis had evidence of an impaired immune response to the attenuated adenovirus Ad26.COV2.S vaccine. 
Patients receiving dialysis may have a less robust antibody response to COVID-19 vaccination, yet have a 10-15 fold higher risk for COVID-19-associated mortality than the general population $^{1,2}$. We previously raised concern about diminished vaccine responses to the attenuated adenovirus SARS-CoV-2 vaccine compared to m-RNA vaccines among patients on dialysis, although the number of patients receiving the attenuated adenovirus vaccine was small ${ }^{2}$. Here we report qualitative and semi-quantitative receptor-binding domain (RBD) antibody responses by vaccine type and dialysis modality in 2,099 patients receiving dialysis.

In partnership with a non-profit dialysis provider that serves patients undergoing dialysis in four states (California, Texas, Tennessee, and New Jersey), we evaluated the humoral vaccination response among patients receiving dialysis. From 6,022 patients receiving dialysis, we identified 2,099 patients who had been fully vaccinated and whom we had tested for SARS-CoV-2 antibody before and at least 14 days after vaccination. The dialysis provider made no recommendations regarding type of vaccine, and administration was based on supply availability. More patients residing in the South were offered the attenuated adenovirus vaccine due to timing (i.e., facilities in the West and East received vaccines at earlier time points, when attenuated adenovirus vaccines were not yet available).

We tested antibody response using the Siemens' total receptor-binding domain (RBD) Ig assay, which measures IgG and IgM antibodies ${ }^{3}$. Among those with a total RBD response, we quantified their antibody response using one of two semiquantitative Siemens RBD IgG assays ${ }^{4}$, 5. We defined "no seroconversion" as lack of change from negative to positive in total RBD Ig antibody, no detectable response on semiquantitative RBD IgG antibody (index value <1) as "no RBD IgG response", and a semiquantitative RBD IgG index value $<10$ as "diminished RBD IgG response" (Supplementary Methods delineates rationale for index value cut points). 
medRxiv preprint doi: https://doi.org/10.1101/2021.08.02.21261516; this version posted August 4, 2021. The copyright holder for this preprint (which was not certified by peer review) is the author/funder, who has granted medRxiv a license to display the preprint in perpetuity.

It is made available under a CC-BY-NC-ND 4.0 International license .

Of the 2,099 fully vaccinated patients on dialysis, the proportion receiving the mRNA1273 (Moderna mRNA), BNT162b2 (Pfizer mRNA), and Ad26.COV2.S (Jonhson and Johnson, attenuated adenovirus) were $62 \%(n=1316), 20 \%(n=416)$ and $18 \%(n=367)$, respectively (Supplement Table 1). Patients vaccinated with the Ad26.COV2.S vaccine were younger, more likely to be non-Hispanic Black, to have prior evidence of SARS-CoV-2 infection, and to reside in the South. Seroconversion to Ad26.COV2.S vaccine occurred later than to the mRNA vaccines (Table 1). Whether assessed during the day 14-28 window post vaccination or in the day 28-60 window post vaccination, however, patients receiving the Ad26.COV2.S vaccine had higher likelhood of no seroconversion and no detectable or diminished IgG response compared with those receiving the mRNA vaccines (Table 1). Patients vaccinated with BNT162b2 had higher prevalence of no detectable or diminished IgG response, compared with patients vaccinated with mRNA1273.

Patients receiving home dialysis with either peritoneal dialysis or home hemodialysis had similar prevalence of no seroconversion and no detectable or diminished IgG response, compared with patients receiving in-center dialysis (Table 1). There was no difference in response rates by vaccine type among the home versus in-center populations.

In this large cohort of patients receiving dialysis, prevalence of no response or diminished response to COVID-19 vaccination varied by vaccine type, with a third of patients receiving the attenuated adenovirus Ad26.COV2.S vaccine failing to seroconvert and an additional third having no detectable or diminished IgG response even 28-60 days post vaccination. Although patients receiving home dialysis represent a cohort with better health and functional status, we observed no difference in response rates by dialysis modality, with similar immunogenicity of the three vaccines in circulation in the US among patients on in-center versus home dialysis. 
Limitations of this study include the concentration of patients in four states and non-random allocation of vaccine type, although the cohort receiving the attenuated adenovirus vaccine were younger and more likely to have had prior SARS-CoV-2 infection, both factors that likely could have improved response. Although a detectable serum antibody response is often equated with immunity, this relationship is not absolute. We were unable to test for cellular immunity or the presence of memory B cells.

Follow-up of vaccinated patients with end-stage kidney disease for clinical COVID-19 will provide a better estimate of vaccine efficacy by vaccine type. Higher rates of spike protein seroconversion after a third dose of mRNA vaccine were recently reported among solidtransplant organ recipients ${ }^{6}$, and in preliminary data among patients on dialysis ${ }^{7}$. Whether additional vaccination doses or change in vaccine type are necessary for a subset of patients receiving dialysis who have failed to seroconvert or have demonstrated weak immune response in the early period post vaccination requires further investigation. 
medRxiv preprint doi: https://doi.org/10.1101/2021.08.02.21261516; this version posted August 4, 2021. The copyright holder for this preprint (which was not certified by peer review) is the author/funder, who has granted medRxiv a license to display the preprint in perpetuity. It is made available under a CC-BY-NC-ND 4.0 International license.

\section{DISCLOSURES}

GMC is on the Board of Satellite Healthcare, a not for profit dialysis organization. SA serves a Medical Director at a Satellite Healthcare dialysis unit. GA, SS, TS and BS are employees of Satellite Healthcare.

\section{FUNDING}

Dr. Garcia was funded by the American Kidney Fund Clinical Scientist in Nephrology Award and the Stanford University School of Medicine Leeds Compassionate Scholar Award. Dr. Anand was supported by R01DK127138. Dr Chertow was supported by K24DK085446. 
medRxiv preprint doi: https://doi.org/10.1101/2021.08.02.21261516; this version posted August 4, 2021. The copyright holder for this preprint (which was not certified by peer review) is the author/funder, who has granted medRxiv a license to display the preprint in perpetuity. It is made available under a CC-BY-NC-ND 4.0 International license .

\section{REFERENCES}

1. De Meester J, De Bacquer D, Naesens M, et al. Incidence, Characteristics, and Outcome of COVID-19 in Adults on Kidney Replacement Therapy: A Regionwide Registry Study. J Am Soc Nephrol. Feb 2021;32(2):385-396. doi:10.1681/ASN.2020060875

2. Anand S, Montez-Rath M, Han J, et al. Antibody Response to COVID-19 Vaccination in Patients Receiving Dialysis. J Am Soc Nephrol. Jun 11 2021;doi:10.1681/ASN.2021050611

3. Siemens Healthineers. SARS-CoV-2 Total Assay. https://statichealthcaresiemenscom/siemens_hwem-hwem_ssxa_websites-contextroot/wcm/idc/groups/public/@global/@lab/documents/download/mda5/ode4/ edisp/total assay_infographic_labversion_final_posteua-07316424pdf. Accessed July 10, 2020 2020;

4. Siemens Healthcare Diagnostics Inc. ADVIA Centaur XP and ADVIA Centaur XPT Systems. 2020. Accessed June 28, 2021. https://www.fda.gov/media/140704/download

5. Siemens Healthcare Diagnostics Inc. Atellica IM Analyzer. 2021. Accessed June 28, 2021. https://www.fda.gov/media/146931/download

6. Kamar N, Abravanel F, Marion O, Couat C, Izopet J, Del Bello A. Three Doses of an mRNA Covid-19 Vaccine in Solid-Organ Transplant Recipients. N Engl J Med. Jun 23 2021;doi:10.1056/NEJMc2108861

7. Ducloux D, Colladant M, Chabannes M, Yannaraki M, Courivaud C. Humoral response after three doses of BNT162b2 mRNA COVID-19 vaccine in patients on hemodialysis. Kidney Int. 2021. 


\section{TABLES}

Table 1. Prevalence of absent or diminished response among fully vaccinated individuals by vaccine type, dialysis modality and overall, between 14 and 28 days and between 28 and 60 days after completion of vaccine*

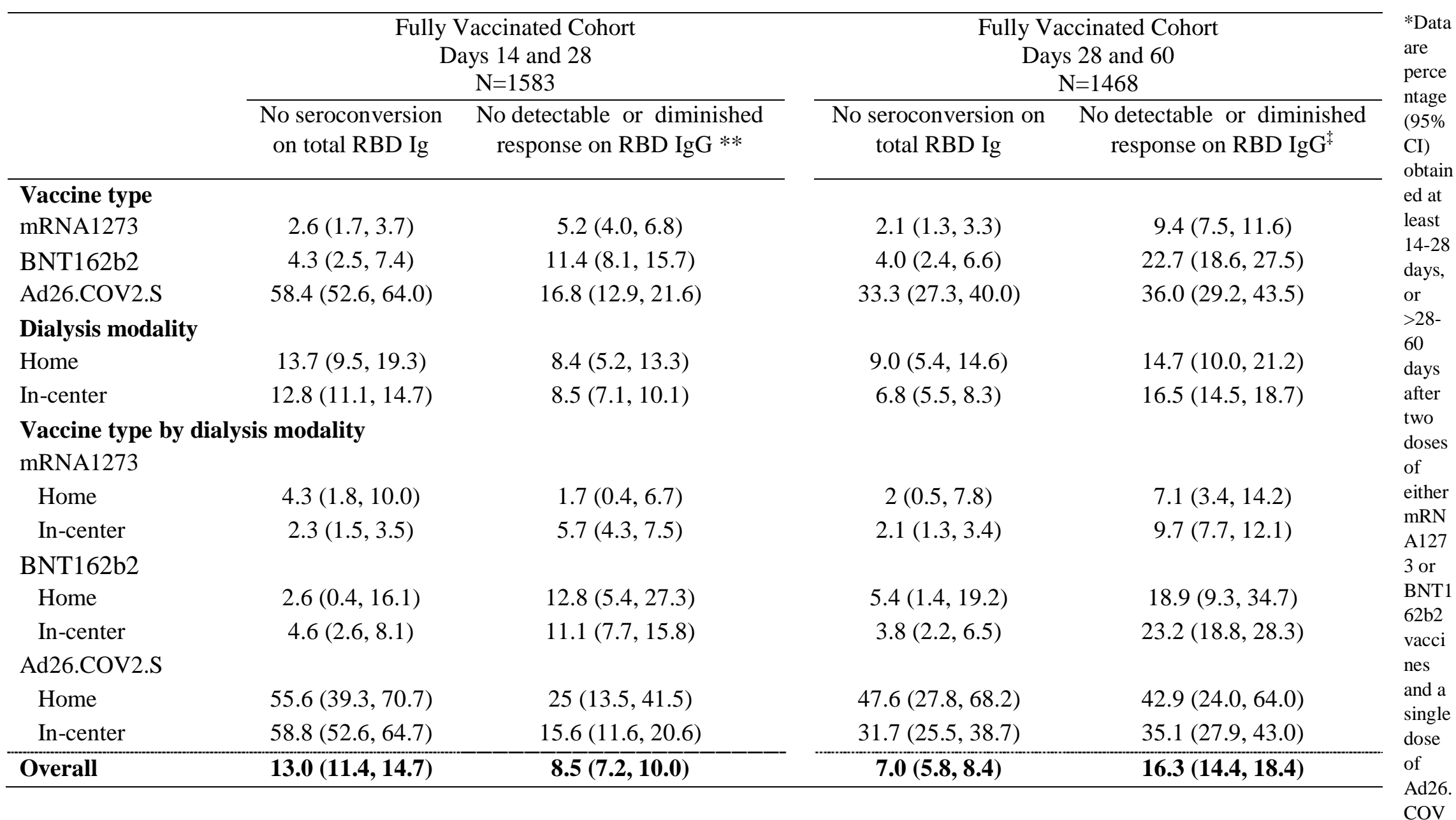

2.S vaccine. Diminished classification refers to semiquantitative $\operatorname{IgG}$ index value $<10$.

$* *$ Total $\mathrm{N}=1532$ due to 51 missing semiquantitative IgG result

$\$$ Total $\mathrm{N}=1326$ due to 142 missing semiquantitative $\mathrm{IgG}$ result 
medRxiv preprint doi: https://doi.org/10.1101/2021.08.02.21261516; this version posted August 4, 2021. The copyright holder for this preprint (which was not certified by peer review) is the author/funder, who has granted medRxiv a license to display the preprint in perpetuity.

\author{
It is made available under a CC-BY-NC-ND 4.0 International license.
}

